\title{
Side-effects of fluticasone in asthmatic children: no effects after dose reduction
}

\author{
M.J. Visser*, E. van der Veer", D.S. Postma*, L.R. Arends ${ }^{\oplus}$, T.W. de Vries ${ }^{+}$, P.L.P. Brand ${ }^{\S}$, \\ E.J. Duiverman ${ }^{f}$
}

Side-effects of fluticasone in asthmatic children: no effects after dose reduction. M.J. Visser, E. van der Veer, D.S. Postma, L.R. Arends, T.W. de Vries, P. L.P. Brand, E.J. Duiverman. (C) ERS Journals Ltd 2004.

ABSTRACT: To assess long-term effects and side-effects of fluticasone propionate (FP), a 2-yr study was performed, comparing a step-down dose approach $\left(1,000 \mu \mathrm{g} \cdot \mathrm{day}^{-1}\right.$, with reductions every 2 months to 500,200 and $100 \mu \mathrm{g} \cdot \mathrm{day}^{-1}$ for the remainder of the study) versus a constant dose $\left(200 \mu \mathrm{g} \cdot \mathrm{day}^{-1}\right)$.

In 55 children with chronic persistent asthma, aged 6-10 yrs, airways hyperresponsiveness (AHR) and systemic side-effects (height, bone parameters and adrenal cortical function) were assessed at predetermined intervals in a double-blind prospective 2-yr study.

AHR improved after 4 months treatment with $1,000 \mu \mathrm{g} \cdot \mathrm{day}^{-1} \mathrm{FP}$ followed by $500 \mu \mathrm{g} \cdot \mathrm{day}^{-1}$, without significant differences during long-term treatment between the two approaches. Dose-dependent reduction of growth velocity, adrenal cortical function and biochemical bone turnover was found during therapy with 1,000 and $500 \mu \mathrm{g} \cdot \mathrm{day}^{-1}$ FP when compared with $200 \mu \mathrm{g} \cdot \mathrm{day}^{-1}$.

In conclusion, doses of 1,000 and $500 \mu \mathrm{g} \cdot \mathrm{day}^{-1}$ fluticasone propionate are associated with marked reductions of growth velocity, bone turnover and adrenal cortical function. However, conventional doses $\left(\leqslant 200 \mu \mathrm{g} \cdot \mathrm{day}^{-1}\right.$ fluticasone propionate) appear to be safe in the long-term management of childhood asthma. From a safety point of view, high doses of fluticasone propionate should only be prescribed in exceptions, $e$.g. in persistent severe asthma.

Eur Respir J 2004; 24: 420-425.
Depts of *Pulmonology, ${ }^{*}$ Pathology and Laboratory Medicine, and ${ }^{f}$ Paediatric Pulmonology, University Hospital Groningen, Groningen, "Dept of Epidemiology and Biostatistics, Erasmus Medical Centre, Rotterdam, ${ }^{+}$Dept of Paediatrics, Medical Centre, Leeuwarden, and ${ }^{\S}$ Dept of Paediatrics, Division of Paediatric Pulmonology, Isala Klinieken, Zwolle, the Netherlands.

Correspondence: M.J. Visser, Dept of Pulmonology, University Hospital Groningen, P.O. Box 30,001, 9700 RB Groningen, the Netherlands.

Fax: 31503619320

E-mail: M.Visser@int.azg.nl

Keywords: Adrenal cortex, bone metabolism, fluticasone, height, hyperresponsiveness

Received: February 252004

Accepted after revision: April 202004

This study was supported by GlaxoSmithKline (the Netherlands), De Stichting Astma Bestrijding, University Hospital Groningen and the University of Groningen.
Inhaled corticosteroids (ICS) are the cornerstone of asthma treatment. As these drugs are highly effective in improving symptoms, lung function, airways hyperresponsiveness (AHR) and quality of life in asthmatic children, they are recommended as controller therapy in all but the mildest forms of childhood asthma [1-4].

Although current guidelines advise treatment with ICS in doses $\leqslant 400 \mu \mathrm{g} \cdot$ day $^{-1}$, it has been advocated to start ICS therapy in childhood asthma with a high dose, in order to reduce airway inflammation powerfully, and to subsequently taper off to the lowest effective dose ("step-down" strategy) [4]. It is also advocated to double the dose of ICS when asthma deteriorates. As a result, high dosages of ICS are frequently used, but very limited data is available on the effects and side-effects of high-dose ICS therapy in children [5]. In a previous report on the same study, the current authors have shown an initial improvement in AHR in children with asthma during high-dose fluticasone propionate therapy (FP; $1,000 \mu \mathrm{g} \cdot \mathrm{day}^{-1}$ for 2 months, followed by 2 months of $500 \mu \mathrm{g} \cdot \mathrm{day}^{-1}$ ) compared with children treated with a constant dose of $200 \mu \mathrm{g} \cdot \mathrm{day}^{-1} \mathrm{FP}$ [6]. When the dose of FP was tapered to $100 \mu \mathrm{g} \cdot \mathrm{day}^{-1}$, no differences were found between asthmatic children treated with this step-down approach and children using $200 \mu \mathrm{g} \cdot \mathrm{day}^{-1} \mathrm{FP}$ during the full 1-yr follow-up. Thus, the step-down approach does not appear to be superior to a constant-dose approach of FP in children with chronic persistent asthma.
Concerns regarding the adverse effects of ICS on growth in children have been relieved by recent reports showing normal height during ICS treatment for 4-6 yrs and normal final height at adult age after long-term ICS therapy (budesonide, mean dose $400 \mu \mathrm{g} \cdot \mathrm{day}^{-1}$ ) [7, 8]. Although effects of ICS on bone mineral density (BMD) in adults have been described, studies in children did not demonstrate reduction of BMD during ICS treatment [7, 9-13]. Even during long-term treatment, therefore, ICS appear to be safe, but clinically relevant systemic side-effects have been reported anecdotally [14-17].

The current report deals with the second year of follow-up of a previously published double-blind study that was designed to compare effects of different dosage schedules of FP during 2-yr follow-up in these asthmatic children, focusing on systemic side-effects.

\section{Methods}

\section{Study subjects and study design}

Recruitment of patients and the study design have been published previously [6]. Briefly, 55 asthmatic children, 6-10 yrs of age, with a diagnosis of mild-to-moderate persistent asthma were recruited from the outpatient clinics of three participating hospitals (University Hospital Groningen, Groningen, and Medical Centre, Leeuwarden, and Isala Klinieken, Zwolle, The Netherlands). Patients were randomised 


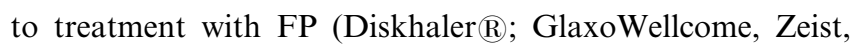
the Netherlands) when they developed AHR (defined as the provocative dose of methacholine causing a $20 \%$ drop in forced expiratory volume in one second (PD20) $<80 \mu \mathrm{g}$ ) after stopping ICS [18]. Study treatment consisted of either $200 \mu \mathrm{g} \cdot \mathrm{day}^{-1} \mathrm{FP}$ for $2 \mathrm{yrs}$ (constant-dose group) or a high starting dose of FP $\left(1,000 \mu \mathrm{g} \cdot \mathrm{day}^{-1}\right)$, followed by reductions every 2 months to 500,200 and $100 \mu \mathrm{g} \cdot \mathrm{day}^{-1}$ during the remaining $1.5 \mathrm{yrs}$ (step-down group) in a double-blind protocol (fig. 1a). Patients were asked to bring all used and unused medication to each follow-up visit, and adherence to treatment was assessed by counting the medication "blisters" used. Randomisation was performed using a computer program with stratification for age, sex, duration of prior ICS use and PD20.

The study was approved by the medical ethics committees of the three participating centres.

\section{Outcome measurements}

Expiratory flow/volume curves were obtained with a Jaeger Masterlab pneumotachograph (Eric Jaeger GmbH, Würzburg, Germany) according to the guidelines of the European Respiratory Society [19]. AHR to methacholine was measured using a dosimeter method as published previously [18]. Patients kept symptom and peak flow diaries during the study. These data have been published previously and will not be reported here [6].

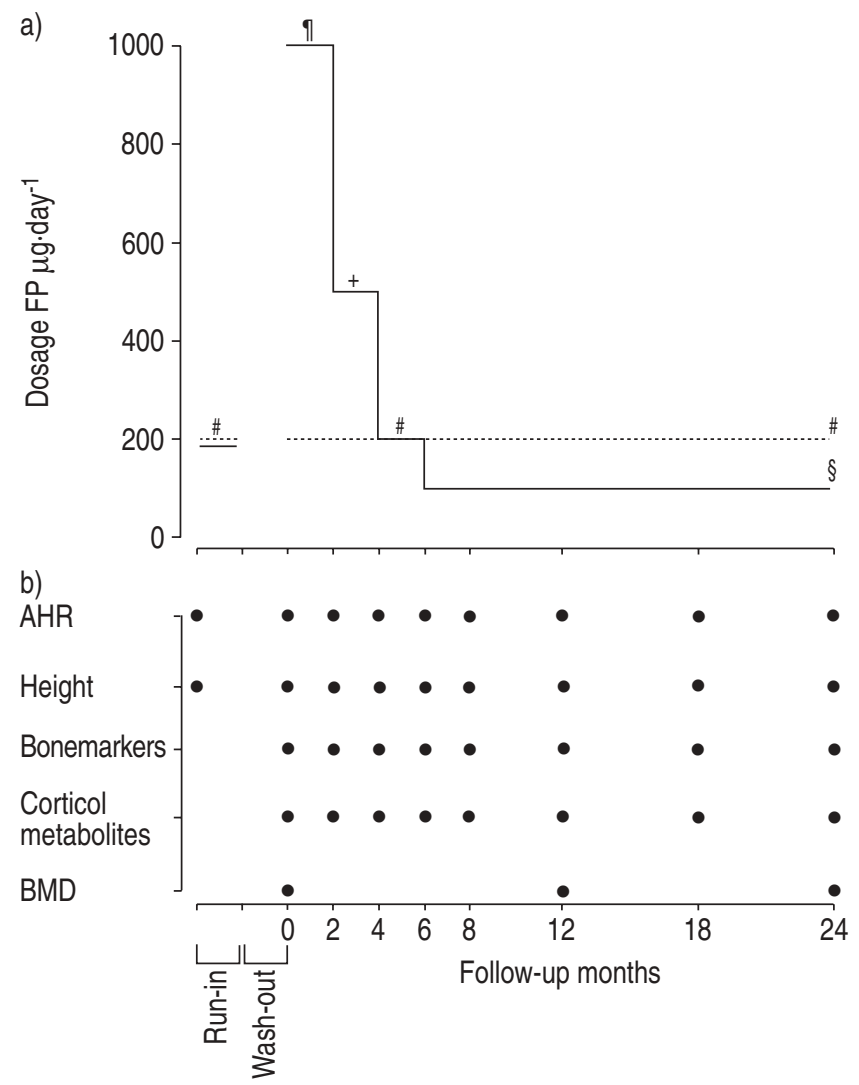

Fig. 1.-a) Study design comparing different dosing schedules (stepdown approach $(-)$; continuous approach $(\cdots \cdots)$ ) of inhaled fluticasone propionate (FP) for 2 yrs in asthmatic children. b) Measurements of airways hyperresponsiveness (AHR), height, bonemarkers, cortisol metabolites and bone mineral density (BMD) were made during the study. Parts of this figure have been previously published [6]. \#. $200 \mu \mathrm{g} \cdot \mathrm{day}^{-1}$; $: 1,000 \mu \mathrm{g} \cdot \mathrm{day}^{-1}$; $^{+}: 500 \mu \mathrm{g} \cdot \mathrm{day}^{-1}$; : $100 \mu \mathrm{g} \cdot \mathrm{day}^{-1}$.
Height was measured at predetermined intervals (fig. 1b) by trained technicians, using a calibrated Harpenden stadiometer (Holtain, Crymych, UK). Growth velocity in $\mathrm{cm} \cdot \mathrm{yr}^{-1}$ was calculated from changes in height over time. Bone age of the left hand was determined at randomisation and after 1 and 2 yrs using the TANNER and WHITEHOUSE method by a single blinded investigator [20]. Tanner's pubertal stages were scored at each follow-up visit [21]. BMD of the spine was measured by dual energy X-ray absorption from L1 to L4, using a Hologic QDR-4500 C Elite (Hologic, Bedford, MD, USA) [22].

Serum osteocalcin and amino-terminal propeptide of type-1 procollagen (P1NP), markers of bone formation, were measured using the immunoradiometric assay of Medgenix-H-Ost (Fleurus, Belgium) and radio-immunosorbent assay kit of Orion Diagnostica (Espoo, Finland), respectively. Urinary deoxypyridinoline (Dpyr) and pyridinoline (Pyr), products of bone degradation, were analysed for calcium and creatinine with a Chemistry Analyser (Merck Mega, Darmstadt, Germany) and for Dpyr and Pyr by high-performance liquid chromatography. Urinary excretion of Dpyr and calcium was corrected for urinary creatinine.

Total cortisol metabolite excretion was measured using $24 \mathrm{~h}$ urine (i.e. urine collected $24 \mathrm{~h}$ before) at preset visits (fig. 1b) by gas/liquid chromatography as described previously [23]. The following major metabolites were determined: tetrahydrocortisone, tertahydrocortisol, allotetrahydrocortisol, $\alpha$-cortol, $\alpha$-cortolone, $\beta$-cortol and $\beta$-cortolone.

\section{Statistical analysis}

Comparisons between and within both treatment groups across time points were performed by a linear mixed model. These comparisons were made both when differences in FP doses between groups were large (first months of the study) and when they were small (fig. 1a). Two-tailed p-values of $\mathrm{p}<0.05$ and $0.05<\mathrm{p}<0.1$ were considered to be statistically significant.

\section{Results}

\section{Subjects}

In total, 55 asthmatic children were included in the study: 27 were allocated to the constant-dose group and 28 to the step-down group. Baseline characteristics are shown in table 1; both treatment groups were comparable. During the 2-yr study, seven children were withdrawn: four from the step-down group (three due to exacerbation, one because of abnormal bone density) and three from the constant-dose

Table 1.-Baseline characteristics at randomisation

Constant-dose group Step-down group

\begin{tabular}{lcc}
\hline Subjects n & 28 & 27 \\
Females n & 13 & 13 \\
Age at study entry yrs & $7.8(0.2)$ & $8.1(0.3)$ \\
Duration of asthma yrs & $5.0(0.4)$ & $5.0(0.4)$ \\
Standing height cm & $129.2(1.7)$ & $132.5(1.7)$ \\
PD20 methacholine $\mu \mathrm{g}$ & $30(22-43)$ & $36(26-53)$ \\
IgE IU L $^{-1}$ & $418(252-695)$ & $560(386-814)$ \\
FEV1 L & $1.41(0.06)$ & $1.53(0.07)$ \\
\hline
\end{tabular}

Data are presented as $\mathrm{n}$, mean (SE) and geometric mean (range). PD20: provocative dose of methacholine causing a $20 \%$ drop in forced expiratory volume in one second; IgE: immunoglobulin E; FEV1: forced expiratory volume in one second. 

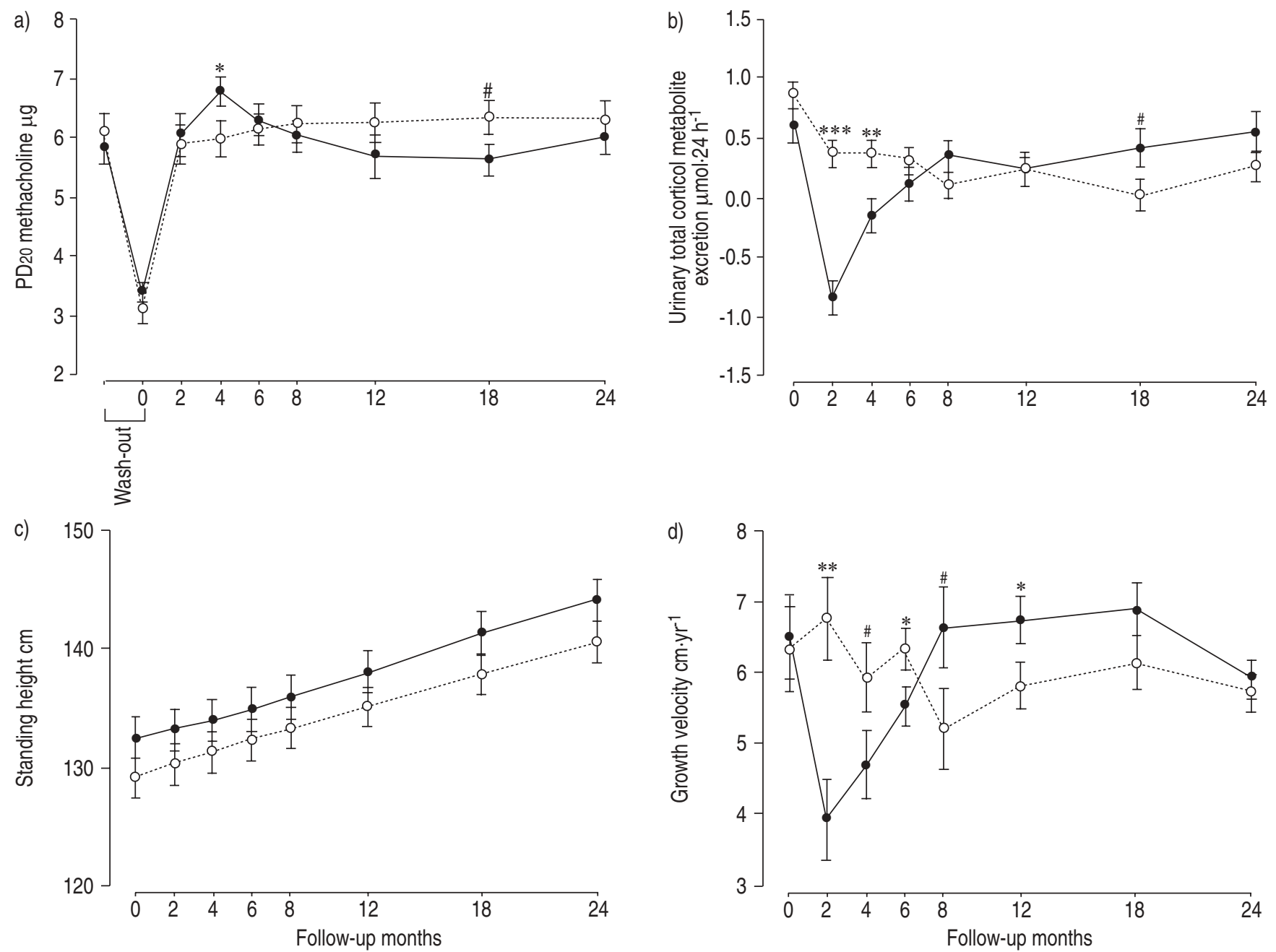

Fig. 2. - a) Airways hyperresponsiveness to the provocative dose of methacholine causing a $20 \%$ drop in forced expiratory volume in one second (PD20) in asthmatic children during and after 2-yr treatment with different dosing schedules (step-down approach $(-)$; continuous approach $(\cdots .$.$) ) of inhaled fluticasone propionate; b) urinary total cortisol metabolite excretion \left(\mu \mathrm{mol} \cdot 24 \mathrm{~h}^{-1}\right.$, corrected for creatinine excretion and body surface area during the 2-yr study period); c) standing height; and d) growth velocity. Parts of figure $2 \mathrm{a}$ and c have been previously published [6]. Data are presented as mean values and bars represent standard error of the mean. *: $\mathrm{p}<0.05 ; * *: \mathrm{p}<0.01 ; *^{* *}: \mathrm{p}<0.001$; ${ }^{\#}: 0.1$ (step-down versus constant-dose group).

group (two because of insufficient asthma control, one due to an exacerbation of asthma). Mean adherence to treatment was $94 \%$ in both groups and remained stable throughout the 2-yr study period.

\section{Airways hyperresponsiveness}

AHR deteriorated during the wash-out period after withdrawal of FP and improved in both groups after reinstitution of inhaled FP (fig. 2a). At 4 months treatment, a statistically significant difference was found between the two groups $\left(500 \mu \mathrm{g} \cdot \mathrm{day}^{-1} \mathrm{FP}\right.$ versus $\left.200 \mu \mathrm{g} \cdot \mathrm{day}^{-1} \mathrm{FP}\right)$. Over the remainder of the 2-yr treatment period, AHR was comparable between the two groups (fig. 2a).

\section{Standing height}

Children in the step-down group were slightly taller (mean $3.3 \mathrm{~cm}$ ) at the start of the study than those in the constantdose group (fig. 2c). Standing height increased comparably in children treated according to the step-down group and the constant-dose group during the 2-yr study. In addition, changes in bone age were similar in the two groups.

\section{Growth velocity}

Growth velocity was similar in the two groups at the start of the study (fig. 2d). A significant dose-dependent negative effect on growth velocity appeared after 2 months treatment $\left(1,000 \mu \mathrm{g} \cdot \mathrm{day}^{-1} \mathrm{FP}\right.$ versus $\left.200 \mu \mathrm{g} \cdot \mathrm{day}^{-1} \mathrm{FP}\right)$. After tapering off $1,000 \mu \mathrm{g} \cdot \mathrm{day}^{-1} \mathrm{FP}$, growth velocity increased when compared with the constant-dose group, which was significant at 6 months $(200 \mu \mathrm{g}$ and $100 \mu \mathrm{g}$ FP versus $200 \mu \mathrm{g})$ and borderline significant at 4 and 8 months treatment (500 and $100 \mu \mathrm{g} \cdot \mathrm{day}^{-1}$ FP versus $200 \mu \mathrm{g} \cdot \mathrm{day}^{-1} \mathrm{FP}$, respectively). After $1 \mathrm{yr}$ of treatment, growth velocity was significantly higher in the step-down group than in the constant-dose group $\left(100 \mu \mathrm{g} \cdot\right.$ day $^{-1} \mathrm{FP}$ versus $\left.200 \mu \mathrm{g} \cdot \mathrm{day}^{-1} \mathrm{FP}\right)$, but this difference had disappeared at the end of the 2-yr treatment period.

\section{Bone markers}

Serum osteocalcin levels did not significantly differ between groups at randomisation (fig. 3a, b and c). Children treated with 1,000 and $500 \mu \mathrm{g} \cdot \mathrm{day}^{-1}$ FP had significantly lower serum osteocalcin levels than children treated with $200 \mu \mathrm{g} \cdot$ day $^{-1} \mathrm{FP}$ 

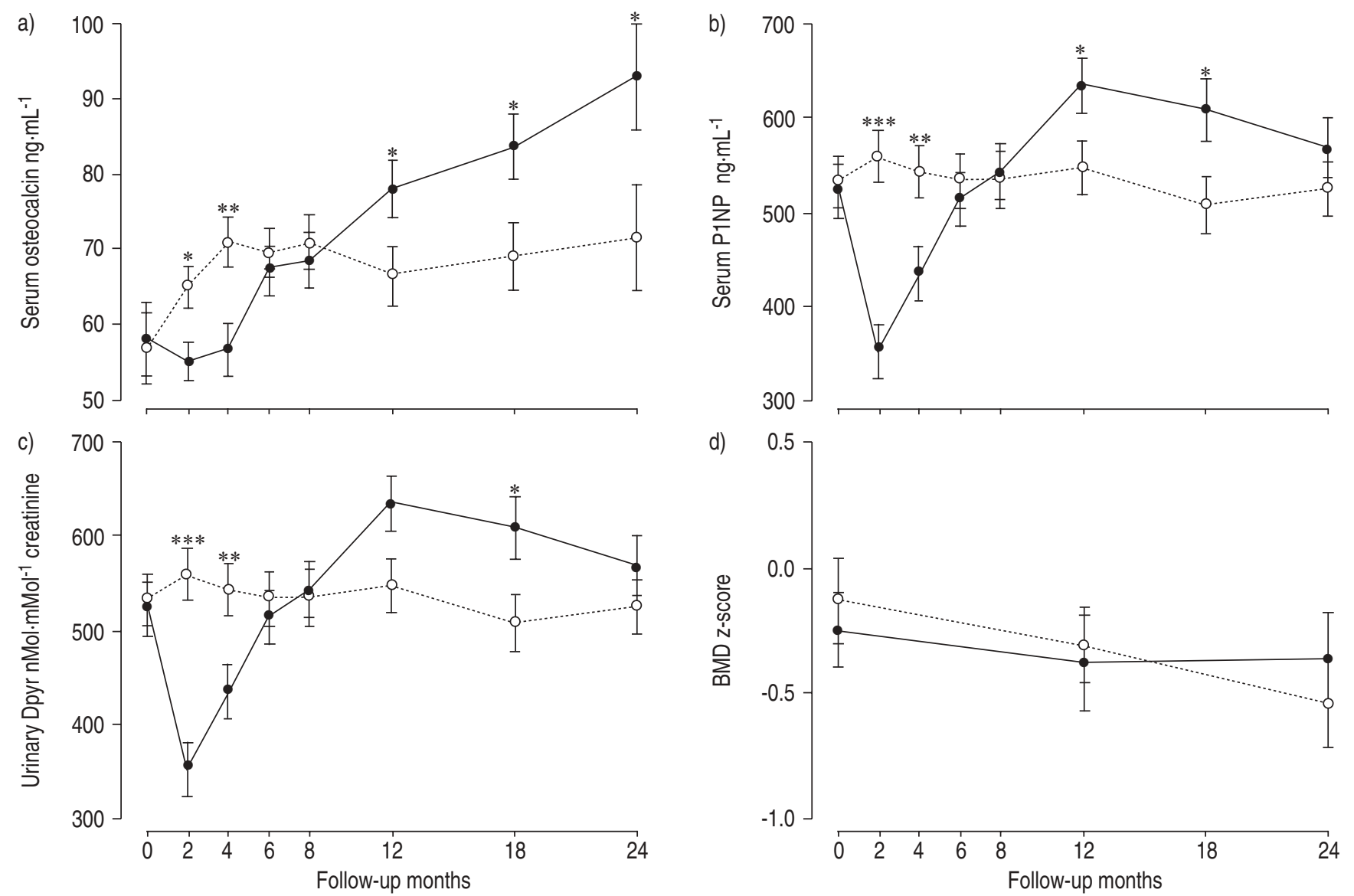

Fig. 3. - Bone turnover markers of inhaled fluticasone propionate in asthmatic children during and after treatment with different dosing schedules (step-down approach $(-)$; continuous approach $(\cdots \cdots)$ ). a) Serum osteocalcin levels $\left(\mathrm{ng} \cdot \mathrm{mL}^{-1}\right)$; b) serum amino-terminal propeptide of type-1 procollagen (P1NP) levels (ng $\left.\cdot \mathrm{mL}^{-1}\right)$; c) urinary deoxypyridinoline (Dpyr) levels (nMol $\cdot \mathrm{mMol}^{-1}$ creatinine); and d) bone mineral density (BMD) $\mathrm{z}$-score. Data are presented as mean values and bars represent standard error of the mean. *: $\mathrm{p}<0.05 ;{ }^{* *}$ : $\mathrm{p}<0.01 ; * * *$ : $\mathrm{p}<0.001$ (step-down versus constant-dose group).

(fig. 3a). When both groups used $200 \mu \mathrm{g} \cdot \mathrm{day}^{-1} \mathrm{FP}$ (at the 6 -month visit) or $200 \mu \mathrm{g}$ and $100 \mu \mathrm{g} \cdot \mathrm{day}^{-1} \mathrm{FP}$ (at the 8 -month visit), serum osteocalcin levels were similar. Thereafter, osteocalcin levels increased during the $100 \mu \mathrm{g} \cdot$ day $^{-1}$ FP treatment, whereas they remained stable in the group using $200 \mu \mathrm{g} \cdot \mathrm{day}^{-1} \mathrm{FP}$ constantly, which resulted in significantly higher osteocalcin levels in the step-down group $\left(100 \mu \mathrm{g} \cdot \mathrm{day}^{-1}\right.$ FP). Both serum P1NP and the urinary Dpyr levels decreased significantly during treatment with 1,000 and $500 \mu \mathrm{g} \cdot \mathrm{day}^{-1} \mathrm{FP}$ compared with $200 \mu \mathrm{g} \cdot \mathrm{day}^{-1}$ FP (fig. $3 \mathrm{~b}$ and c). After 12 and 18 months treatment, a significantly higher P1NP level was present in the step-down group $\left(100 \mu \mathrm{g} \cdot \mathrm{day}^{-1} \mathrm{FP}\right)$ compared with the constant-dose group $\left(200 \mu \mathrm{g} \cdot \mathrm{day}^{-1} \mathrm{FP}\right.$; fig. $\left.3 \mathrm{~b}\right)$, which became similar after 24 months. Urinary Dpyr levels in the step-down group $\left(100 \mu \mathrm{g} \cdot \mathrm{day}^{-1} \mathrm{FP}\right)$ were only significantly higher after 18 months treatment when compared with the constant-dose group $\left(200 \mu \mathrm{g} \cdot \mathrm{day}^{-1} \mathrm{FP}\right.$; fig. $3 \mathrm{~b}$ and c).

The results of the urinary Pyr levels were similar to the Dpyr levels (data not shown) and the ratio of urinary Pyr/ Dpyr was similar between the two groups at all time points of the study.

\section{Bone mineral density}

BMD was similar at baseline, 1-yr and 2-yr treatment in both groups and changes between visits and between groups were not significant (fig. 3d).

\section{4-h urinary cortisol metabolite excretion}

After randomisation, urinary cortisol metabolite excretion was significantly lower during treatment with 1,000 and $500 \mu \mathrm{g} \cdot \mathrm{day}^{-1} \mathrm{FP}$ when compared to $200 \mu \mathrm{g} \cdot \mathrm{day}^{-1} \mathrm{FP}$ (fig. 2b). No further significant differences were found between the groups.

\section{Discussion}

This study investigated the long-term side-effects of ICS in childhood asthma in a prospective way. Children were either treated with a constant dose of FP $\left(200 \mu \mathrm{g} \cdot \mathrm{day}^{-1}\right)$ or in accordance with a step-down strategy, with a very high starting dose of FP $\left(1,000 \mu \mathrm{g} \cdot \mathrm{day}^{-1}\right)$, tapering down over a period of 6 months to a low maintenance dose $\left(100 \mu \mathrm{g} \cdot \mathrm{day}^{-1}\right)$. The current authors previously demonstrated that the step-down strategy was not superior to the constant-dose strategy over a 12-month period, with respect to symptoms, exacerbation rates, lung function and AHR [6]. In addition, the present results show that the second year provided no differences in asthma control $\left(200 \mu \mathrm{g} \cdot \mathrm{day}^{-1} \mathrm{FP}\right.$ versus $\left.100 \mu \mathrm{g} \cdot \mathrm{day}^{-1} \mathrm{FP}\right)$. The current study strongly suggests, therefore, that a step-down strategy is not superior to a constant-dose strategy in the long-term management of childhood asthma. It should be noted, however, that the 
children in this study had all been using ICS prior to entering the study, being school-aged children with mild-to-moderate persistent asthma. Further studies are needed to assess whether a step-down strategy is superior to a constant-dose treatment schedule in steroid-naïve children with newly diagnosed asthma or in children with mild or severe persistent asthma.

During the later stages of the study, when the dose of FP was $\leqslant 200 \mu \mathrm{g}$ in both treatment groups, there were no between-group differences in terms of safety parameters. Standing height, growth velocity, serum P1NP, urinary Dpyr excretion, BMD and adrenal function as assessed by cortisol metabolite excretion were all comparable between groups at the end of the study (figs 2 and 3). Moreover, most parameters did not change from baseline, when no ICS were used for a maximum of 8 weeks, to the end of the study in the group using a constant dose of $200 \mu \mathrm{g} \cdot \mathrm{day}^{-1} \mathrm{FP}$ (figs 2 and 3). These observations are in accordance with earlier work showing that maintenance treatment with a regular and constant dose of ICS, i.e. $200 \mu \mathrm{g} \cdot \mathrm{day}^{-1} \mathrm{FP}$ in the current study, has no systemic side-effects on bone turnover, height and adrenal cortical function [24-29].

Two parameters of bone metabolism did not follow this pattern. Initially, serum levels of osteocalcin, a parameter of bone formation, were lower in the step-down group when doses of 1,000 and $500 \mu \mathrm{g} \cdot \mathrm{day}^{-1} \mathrm{FP}$ were used, but increased when the FP dose was tapered off to $100 \mu \mathrm{g} \cdot \mathrm{day}^{-1}$ to significantly higher levels than those in the constantdose group (fig. 3a). Until now, no studies have examined the effects of different dosages of ICS on osteocalcin levels in children. Although one retrospective study and one nonrandomised open study showed reduced osteocalcin levels during ICS therapy, two randomised clinical trials showed no effect of beclomethasone in doses $\leqslant 400 \mu \mathrm{g} \cdot \mathrm{day}^{-1}$ or $200 \mu \mathrm{g} \cdot \mathrm{day}^{-1} \mathrm{FP}$ on serum osteocalcin [30-33]. The relevance of the dose-dependent effects of inhaled FP on serum osteocalcin levels observed in this study is unclear (fig. 3a). Nevertheless, it is not reflected in effects on BMD, which remained stable throughout the study (fig. 3d). The current authors' results, like others, suggest that serum osteocalcin and BMD represent different phases of bone metabolism, with biochemical bone markers reflecting continuous remodelling and BMD reflecting long-term structural changes [33].

The current study clearly shows a negative direct effect of high-dose FP on biochemical bone turnover parameters, which abate after treatment with lower doses for $\leqslant 2$ yrs. Throughout the study, BMD did not differ significantly between the two study arms, suggesting no detrimental effect of overall long-term use of FP on BMD in asthmatic children. Within the group treated with a constant dose of $200 \mu \mathrm{g} \cdot \mathrm{day}^{-1}$ FP, a trend towards a decrease in BMD in the first year was observed, which became statistically significant in the second year of treatment. This result should be interpreted with caution. It contrasts with the Childhood Asthma Management Program study where $200 \mu \mathrm{g}$ of budesonide $\cdot$ day $^{-1}$, given during 4-6 yrs, did not affect BMD [7].

Moreover, the current study was not double-blinded with placebo and other long-term studies with FP in children are lacking. Finally, the step-down group used a higher cumulative dose of FP during the first year $(120,000 \mu \mathrm{g})$ than the constant-dose group $(72,000 \mu \mathrm{g})$; nevertheless, changes in $\mathrm{BMD}$ in the step-down group were not significant. Thus, there were no significant differences in BMD changes over time between the two study groups and, if anything, a worsening of BMD only in the group treated with the overall lowest dose. Clearly, further long-term studies are needed to evaluate effects of low-dose ICS treatment on BMD in children.
The most prominent finding of the current study is the marked negative effects of high-dose FP (1,000 and $\left.500 \mu \mathrm{g} \cdot \mathrm{day}^{-1}\right)$ on growth velocity and adrenal cortical function (fig. 2) and on biochemical markers of bone turnover and BMD (fig. 3). A reassuring finding is that these effects are short-lived and fully reversible when the dose of FP is tapered down. Furthermore, prolonged use of ICS may provide less negative effects than short-term therapy [34]. In any case, the magnitude of the observed findings warrants a note of caution because it suggests a clear potential for clinically relevant side-effects if high dosages of FP are continued for prolonged periods of time. Indeed, clinically relevant growth suppression and adrenal failure have been described anecdotally in children receiving high-dose FP therapy [15, 35-38].

In conclusion, the current study shows that maintenance therapy with inhaled fluticasone propionate in dosages of $\leqslant 200 \mu \mathrm{g} \cdot \mathrm{day}^{-1}$ appears to be safe in the long-term management of childhood asthma. Nevertheless, marked reduction of growth velocity, biochemical bone turnover and adrenal cortical function occurs during treatment with high dosages of inhaled fluticasone propionate. Given the current findings that high-dose fluticasone propionate therapy is no more effective than a "regular dose" and that it may cause clinically significant side-effects, it is proposed that high dosages of inhaled fluticasone propionate should be prescribed for exceptions, e.g. in persistent severe asthma. These results provide a guideline to use the lowest effective dose of inhaled corticosteroids in order to prevent systemic side-effects.

\begin{abstract}
Acknowledgements. The authors thank A.W.A. Kamps for including the children and collecting the data, D.A. Piers for performing the bone mineral density measurements, and J.C. van der Molen and G. Hofstede for performing the laboratory measurements during the study.
\end{abstract}

\section{References}

1. Calpin C, Macarthur C, Stephens D, Feldman W, Parkin PC. Effectiveness of prophylactic inhaled steroids in childhood asthma: a systemic review of the literature. J Allergy Clin Immunol 1997; 100: 452-457.

2. Adams N, Bestall J, Jones PW. Inhaled fluticasone proprionate for chronic asthma. Cochrane Database Syst Rev 2001; 3: CD003135.

3. National Heart, Lung and Blood Institute, National Institutes of Health. International consensus report on diagnosis and treatment of asthma (NHLBI publication no. 92-3091, March 1992). Eur Respir J 1992; 5: 601-641.

4. The British Guidelines on Asthma Management 1995. Review and Position Statement. The General Practitioner in Asthma Group, the British Association of Accident and Emergency Medicine, the British Paediatric Respiratory Society and the Royal College of Paediatrics and Child Health. Thorax 1997; 52: Suppl. 1, S2-S20.

5. Adams N, Bestall JM, Jones PW. Inhaled fluticasone at different doses for chronic asthma. Cochrane Database Syst Rev 2002; 1: CD003534.

6. Visser MJ, Postma DS, Arends LR, de Vries TW, Duiverman EJ, Brand PL. One-year treatment with different dosing schedules of fluticasone propionate in childhood asthma. Effects on hyperresponsiveness, lung function, and height. Am J Respir Crit Care Med 2001; 164: 2073-2077.

7. The Childhood Asthma Management Program Research Group. Long-term effects of budesonide or nedocromil in children with asthma. N Engl J Med 2000; 343: 1054-1063.

8. Agertoft L, Pedersen S. Effect of long-term treatment with 
inhaled budesonide on adult height in children with asthma. $N$ Engl J Med 2000; 343: 1064-1069.

9. Israel E, Banerjee TR, Fitzmaurice GM, Kotlov TV, LaHive $\mathrm{K}$, LeBoff MS. Effects of inhaled glucocorticoids on bone density in premenopausal women. N Engl J Med 2001; 345: 941-947.

10. Wong CA, Walsh LJ, Smith CJ, et al. Inhaled corticosteroid use and bone-mineral density in patients with asthma. Lancet 2000; 355: 1399-1403.

11. Reilly SM, Hambleton G, Adams JE, Mughal MZ. Bone density in asthmatic children treated with inhaled corticosteroids. Arch Dis Child 2001; 84: 183-184.

12. Baraldi E, Bollini MC, De Marchi A, Zacchello F. Effect of beclomethasone dipropionate on bone mineral content assessed by X-ray densitometry in asthmatic children: a longitudinal evaluation. Eur Respir J 1994; 7: 710-714.

13. Agertoft L, Pedersen S. Bone mineral density in children with asthma receiving long-term treatment with inhaled budesonide. Am J Respir Crit Care Med 1998; 157: 178-183.

14. Zwaan CM, Odink RJ, Delemarre-van de Waal HA, Dankert-Roelse JE, Bokma J. Acute adrenal insufficiency after discontinuation of inhaled corticosteroid therapy. Lancet 1992; 340: 1289-1290.

15. Todd G, Dunlop K, McNaboe J, Ryan MF, Carson D, Shields MD. Growth and adrenal suppression in asthmatic children treated with high-dose fluticasone propionate. Lancet 1996; 348: 27-29.

16. Priftis K, Everard ML, Milner AD. Unexpected side-effects of inhaled steroids: a case report. Eur J Pediatr 1991; 150: $448-449$

17. Wong JY, Zacharin MR, Hocking N, Robinson PJ. Growth and adrenal suppression in asthmatic children on moderate to high doses of fluticasone propionate. $J$ Paediatr Child Health 2002; 38: 59-62.

18. Birnie D, thoe Schwartzenberg GW, Hop WC, van EssenZandvliet EE, Kerrebijn KF. Does the outcome of the tidal breathing and dosimeter methods of assessing bronchial responsiveness in children with asthma depend on age? Thorax 1990; 45: 199-202.

19. Quanjer PH, Tammeling GJ, Cotes JE, Pedersen OF, Peslin R, Yernault JC. Lung volumes and forced ventilatory flows. Report Working Party Standardization of Lung Function Tests, European Community for Steel and Coal. Official Statement of the European Respiratory Society. Eur Respir J Suppl 1993; 16: 5-40.

20. Tanner JM, Whitehouse RH, Cameron N, Marshall WA, Healy MJR, Goldstein H. Assessment of skeletal maturity and prediction of adult height (TW2 method). London, Acad Press, 1983.

21. Tanner JM. Normal growth and techniques of growth assessment. Clin Endocrinol Metab 1986; 15: 411-451.

22. Kinberg KA, Hopp RJ, Biven RE, Gallagher JC. Bone mineral density in normal and asthmatic children. $J$ Allergy Clin Immunol 1994; 94: 490-497.

23. Steen G, Tas AC, Ten Noever De Brauw MC, Drayer NM,
Wolthers BG. The early recognition of the 21-hydroxylase deficiency variety of congenital adrenal hyperplasia. Clin Chim Acta 1980; 105: 213-224.

24. Wolthers OD, Riis BJ, Pedersen S. Bone turnover in asthmatic children treated with oral prednisolone or inhaled budesonide. Pediatr Pulmonol 1993; 16: 341-346.

25. Wolthers OD, Hansen M, Juul A, Nielsen HK, Pedersen S. Knemometry, urine cortisol excretion, and measures of the insulin-like growth factor axis and collagen turnover in children treated with inhaled glucocorticosteroids. Pediatr Res 1997; 41: 44-50.

26. Brand PL. Inhaled corticosteroids reduce growth. Or do they? Eur Respir J 2001; 17: 287-294.

27. Pedersen S. Do inhaled corticosteroids inhibit growth in children? Am J Respir Crit Care Med 2001; 164: 521-535.

28. Priftis K, Milner AD, Conway E, Honour JW. Adrenal function in asthma. Arch Dis Child 1990; 65: 838-840.

29. Yiallouros PK, Milner AD, Conway E, Honour JW. Adrenal function and high dose inhaled corticosteroids for asthma. Arch Dis Child 1997; 76: 405-410.

30. Crowley S, Trivedi P, Risteli L, Risteli J, Hindmarsh PC, Brook CG. Collagen metabolism and growth in prepubertal children with asthma treated with inhaled steroids. $J$ Pediatr 1998; 132: 409-413.

31. Sorva $\mathrm{R}$, Tahtela $\mathrm{R}$, Turpeinen $\mathrm{M}$, et al. Changes in bone markers in children with asthma during inhaled budesonide and nedocromil treatments. Acta Paediatr 1996; 85: 11761180 .

32. Doull I, Freezer N, Holgate S. Osteocalcin, growth, and inhaled corticosteroids: a prospective study. Arch Dis Child 1996; 74: 497-501.

33. Rao R, Gregson RK, Jones AC, Miles EA, Campbell MJ, Warner JO. Systemic effects of inhaled corticosteroids on growth and bone turnover in childhood asthma: a comparison of fluticasone with beclomethasone. Eur Respir J 1999; 13: 87-94.

34. Kerstjens HA, Postma DS, van Doormaal JJ, et al. Effects of short-term and long-term treatment with inhaled corticosteroids on bone metabolism in patients with airways obstruction. Dutch CNSLD Study Group. Thorax 1994; 49: $652-656$

35. Todd GR. Side-effects of high-dose fluticasone propionate in children. Eur Respir J 1999; 13: 707-709.

36. Todd GR, Acerini CL, Ross-Russell R, Zahra S, Warner JT, McCance D. Survey of adrenal crises associated with inhaled corticosteroids in the United Kingdom. Arch Dis Child 2002; 87: 457-461.

37. Todd GR, Acerini CL, Buck JJ, et al. Acute adrenal crisis in asthmatics treated with high-dose fluticasone propionate Eur Respir $J$ 2002; 19: 1207-1209.

38. Sim D, Griffiths A, Armstrong D, Clarke C, Rodda C, Freezer N. Adrenal suppression from high-dose inhaled fluticasone propionate in children with asthma. Eur Respir J 2003; 21: 633-636. 